\title{
The Investigation of Lexical and Discourse-based Communication Strategies Used by EFL Teachers in the Classrooms
}

\section{Ali Sorayyaei Azar (Senior Lecturer)}

English Department, Maragheh Branch Islamic Azad University, Maragheh, Iran asorayaie@yahoo.co.uk

\section{Reza Mohammadzadeh (MA Student)}

English Department, Maragheh Branch Islamic Azad University, Maragheh, Iran Rmohammadzadeh31@yahoo.com

\section{Doi:10.5901/jesr.2013.v3n2p317}

\section{Abstract}

Researchers have raised the notion of second Language communication strategies at the beginning of 1970s. These strategies have been defined as a mutual attempt of two interlocutors to agree on a meaning in situations where requisite meaning structures do not seem to be shared. This study was an attempt to investigate lexical and discourse-based communication strategies used by teachers as opposed to previous studies which have considered communication strategies used by students. The study focused on Iranian English as Foreign Language (EFL) teachers and conducted in Miyandoab, Iran. For this purpose forty teachers were selected from English language institutes. An integrated taxonomy of scholars was used as a questionnaire. Quantitative data analysis techniques were then used to analyze the data. A paired t-test was used to analyze the collected data. Principal statistical analyses including frequencies, means, and standard deviations revealed that there was a significant difference between teachers in terms of using lexical and discourse- based communication strategies. The results showed that the EFL teachers used achievement lexical based Communication Strategies to compensate the break downs and they mostly used discourse-based communication strategies to enhance the effectiveness of communication and to show the salience of the topic. The findings of this study will have some pedagogical implications for the area of English language teaching and learning.

Keywords: communication strategies, communicative competence, discourse based communication strategies, lexical based communication strategies

\section{Introduction}

The notion of Second Language Communication Strategies (CSs) was first raised by researchers at the beginning of the 1970s. CSs have been generally defined as the means that L2 speakers use to overcome the difficulties or breakdowns in communication which they confront as a mismatch between their linguistic resources and communication intentions. Researchers believe that these CSs comprise a systematic language phenomenon. Actually if one would take a piece of unplanned $L 2$ oral discourse and analyze it, he would detect the numerous times the speaker has used CSs to overcome the existing gap of knowledge. In fact, everyday conversation is filled with these kinds of efforts and struggles.

Therefore, this is one of the most important reasons why the area of strategic language use has become of great attention during the last few decades. The evidence for this great attention is reflected in the considerable amount of research in this field on the nature of CSs, different CS taxonomies, factors influencing their use and the practical implications of CS research. Up to now there has been "no universally accepted definition of CS" (Dörnyei and Scott, 1997). This unfortunate fact is the explanation for several different taxonomies of CSs which 
include various language devices (Bialystock, 1990; Dörnyei and Scott, 1997; Færch and Kasper, 1983b; Paribakht, 1985 Poulisse, 1983; Tarone, 1997; Willems, 1987).

There has been a great deal of research on the factors which influence the CS use such as task type, speaker's proficiency level, first language (L1) interference, and CS training effectiveness due to lack of conformity on CS definition. So some researchers (Bialystock, 1990; Dörnyei and Scott, 1997) believe that before any further exploration of the area, one must agree on a universal and clear-cut definition.

All of the empirical studies mentioned above which led to different taxonomies, were based on the oral discourse of L2 speakers or learners. In other words, the participants using CSs were always of the lower L2 proficiency level. It seems that researchers have neglected the other present side of the interaction including $L 2$ teachers which are of the higher L2 proficiency. According to Tarone (1980), CS "relates to mutual attempts of two interlocutors to agree on meaning in situations where requisite meaning structures do not seem to be shared." She believes that CSs defined in this way function as 'bridges' over the linguistic knowledge gap between L2 learner and target language interlocutor. In teaching contexts the role of the teachers as one side of the 'bridge' is very significant and essential to the $L 2$ learners. Teachers, as the $L 2$ proficient interlocutor must lead the learners toward dealing with the emerging mismatches and unshared meanings.

The present study is an attempt to identify lexical and discourse- based communication strategies used by the other side of the interaction in teacher-learner classroom discourse. Sometimes EFL teachers like learners to use communication strategies but unfortunately it has been reported that they use some L1 based strategies (i.e. code switching and literal translation) to compensate the breakdown in communication. The teacher's use of L1 based strategies discourages parents to send children to conversation classes. In the present research we are going to identify the communication strategies used by other side of the interaction in teacherlearner classroom discourse. The researchers want to clarify the techniques that the higher proficient interlocutor uses to bridge the linguistic knowledge gaps. The purpose of this study, therefore, is to identify the CSs used by teachers in Iranian English Language Teaching (ELT) classrooms, and to determine which types of CS are used more frequently. In the following section, a review of the related and empirical literature is presented.

\section{Review of Related Literature}

Tarone conducted a research on L2 proficiency and strategy selection. She ranked her subjects in what Biaystok estimated to be a rough order of proficiency to English $(1977$, p.202) and tabulated the number of times they used each strategy. The resulting distribution showed different selection patterns for each of the nine subjects (although paraphrase was usually the preferred strategy). Tarone acknowledges that personality differences among the subjects may account for these patterns, but claims as well 'that strategy preferences and secondlanguage proficiency level may prove to be related' (p.202).

Bialystok (1983) examined the role of language proficiency in L2 learners' use of communication strategies by 17-year-old students in a French second language class. The students were taken from either an advance or a regular class, and their grades, test scores, and pretest results (all the students were administrated a cloze test to asses their proficiency in French) confirmed the designation as advanced or regular. The results showed that the advanced students used proportionally more L2-based strategies than did the regular students, who relied more on the L1-based strategies.

Other studies have also produced equivocal results. The detailed taxonomy developed by Paribakht (1985) allowed her to examine precise relations between speaker proficiency and strategy choice. In her study, native speakers of Persian, who were advanced or intermediate learners of English, and native speakers of English completed a set of communication tasks. Their strategic choices were examined in terms of the four approaches that organized her taxonomy: linguistic; contextual; conceptual; and mime. There were some differences between the groups for three of the four approaches, but no consistent pattern. The linguistic approach was used most often by the native English speakers and advanced learners. These were the two groups with the greatest linguistic resources, so were perhaps most able to use this approach. The contextual approach was used equally by all three groups. The conceptual approach was used most by the intermediate learners. This is perhaps a compensatory strategy for the lack of use of the linguistic approach. Mime was used by the learners more than by the native English speakers. Again, nonstrategic reasons for this difference can be imagined. 
Possibly the two learners needed to compensate more for lack of linguistic resources, or possibly cultural differences made the choice of mime more natural for the learner groups.

Clennell (1996) investigated the pedagogic status of discourse-based communication strategies teaching. His study investigated a case for teaching the pragmatic (discourse-based) features of English intonation to overseas students studying on tertiary level ELT courses, in order to improve cross-cultural communication at both receptive and productive stages. Drawing data from advanced level EAP learners, it advocates a systematic approach to the teaching of pragmatic and discourse-based CSs of English through an investigated consciousness-raising methodology.

Wendy (2006) examined the effects of oral communication strategy teaching (OCST) on learners' performance and on strategy use. Two classes in the secondary ESL classroom in Hong Kong participated in the study; one class received 16 hours of OCST and the other served as a comparison group. In weeks 1, 10 and 20, data were collected from the learners' performance in group work discussions, self-report questionnaires, observations of learners' strategy use, and stimulated recall interviews. The findings indicate that the treatment class generally outperformed the comparison class.

Aliakbari and Karimialvar (2008) studied communication strategies in written medium. Accordingly, the study aimed at pitting the use of CS against language proficiency level in argumentative writing of Iranian university students. The results revealed that language proficiency was highly related with the use of more reconceptualization strategies which are thought to be psychololinguistically more demanding compared with substitution strategies.

Ting and Phan (2008) conducted a research on how the use of communication strategies was influenced by the target language proficiency of speakers of English as an Additional Language and their interlocutors. The oral interaction data from 20 participants in Malaysia were analyzed to identify the choice of communication strategies and type of communication strategy category, using an integrated framework comprising psycholinguistic (Færch and Kasper 1980), interactional (Tarone 1980) and discourse (Clennell 1995) perspectives. The results showed that the two groups did not differ in the total number of communication strategies used, and the preference was for strategies based on the second language (L2). Less proficient speakers inclined towards strategies based on first language (L1), language switch in particular, to overcome communication difficulties. More proficient speakers were able to use tonicity to show salience of information to enhance the negotiation of meaning. The proficient speakers compensated for lack of linguistic ability in their interlocutors, and the conversational adjustment was characterized by the diversified use of lexical repletion to maintain the conversation.

However, the available literature is admittedly slim on empirical research on teacher's use of lexical and discourse based communication strategies is a matter of concern worldwide. Therefore, much more information is needed on the nature of mentioned phenomenon. This study is an attempt to increase our understanding of CSs used by teachers as more proficient interlocutors.

\section{Methodology}

\subsection{The Participants}

Forty EFL teachers at language institutes in Miyandoab, Iran participated in this study. Twenty eight of teachers were male and twelve of them were female. All the participants had graduated from a university in English language field. They graduated from language teaching or English literature. They had almost five years' experience in teaching in conversation classes. The teachers aged from 24-35.

\subsection{The Instrument}

The instrument used in the study was a questionnaire prepared by the researchers to achieve the objective of the current research. The integration of Tarone's (1977) interactional, Farch and Kaspr's (1983) psychological and Clennell's (1995) discoursal typology was used as a questionnaire. The questionnaire included several open and close questions along with some required information to make sure that the teacher understands the purpose of 
the questionnaire and its content. The first part of the questionnaire consists of general questions about the teachers themselves, their experience in teaching and their familiarity with the area of communication strategies.

The second part of the questionnaire offers a brief introduction of CSs. Then for more clarification the selected typology enriched with descriptions and examples to make it more tangible. After the complete description of each strategy, there is a part asking teachers' opinion about their use of that specific communication strategy. The options teachers are supposed to choose range from 'almost always' to 'never' with 'sometimes', 'every once in a while' and 'rarely' in between. This type of technique is very similar to Likert s' (1932) scale in the aspect of involving a five part division in the choices based on their degree compared to the other options available. This scale asks the responders to answer to a series of statements by choosing 'strongly agree, agree, undecided, disagree, strongly disagree' for each statement.

\subsection{The Data Collection Procedure}

The researchers decided to collect the required data from among language institute teachers. For two reasonslanguage institutes were selected for collecting data: first, there is a greater chance of the required type of interaction happening in a private language classroom because the students are obliged to speak in English and the teacher is not allowed to talk in Farsi, and the second reason was that attending the institute and talking to teachers for several times is much more convenient at a private institute than a state school.

At first we decided to gather all the participants in each institute and explain them what we intended to do by the questionnaire. We didn't mention the research questions or even the general topic. The reason was to prevent a probable change in the teachers' answers with the purpose of emitting the investigated item. Although all teachers had graduated in English language, as some of them had studied English Literature and some had graduated a few years ago, we decided to explain the information provided and the questions asked in a face to face conversation to make sure there will be no misunderstanding on the teacher side. The class time devoted for teachers in each institute lasted for an hour and half because the teacher's entire schedule was so tight that getting even the necessary time was very difficult. First, the participants were ensured that the information gained from them would be kept strictly confidential. The teachers were informed that the survey would have no effect on their job. The questionnaires were gathered later after a few days, giving the teachers enough time to think on the questions and answer them carefully and honestly. The data received from teacher's opinions constituted the major sources for statistical analysis. The results were reported qualitatively by presenting every individual teacher's comment and quantitatively by showing the percentages that comments represent.

\subsection{Data Analysis Procedure}

The analysis mainly focused on investigating lexical and discourse- based CSs used by EFL teachers. The data which was received from teacher's answers on questionnaire was fed into computer and analyzed and interpreted following the grounded theory data analysis techniques and procedures. The results were analyzed in the form of paired t-test and data were calculated using SPSS software.

\section{Results}

In this section, the results of the study are discussed in the light of the research objective. The data consisted of the participants' answers on the questionnaire like the Likert Scale. The obtained data by the participants based on their answers related to the use of lexical and discourse based CSs were compared.

EFL teachers try to use achievement communication strategies (paraphrase, circumlocution, and demonstration) to compensate the breakdowns in communication and they mostly use discourse-based communication strategies to improve the effectiveness of communication.

To test the research question of this study paired samples test was conducted to investigate teacher's use of lexical and discourse-based CSs. Tables 4.1, 4.2 and 4.3 show the Paired Samples Statistics, Paired Samples Correlations and Paired Samples Test respectively for comparing teachers in terms of using lexical and discourse based CSs. 
Table 4.1. Paired Samples Statistics for comparing teacher's use of lexical and discourse based CSs

\begin{tabular}{|ll|l|l|l|l|}
\hline & & Mean & N & Std. Deviation & Std. Error Mean \\
\hline Pair 1 & Lexical & 27.4375 & 40 & 9.26355 & 1.46470 \\
& Discourse & 89.5000 & 40 & 6.58281 & 1.04083 \\
\hline
\end{tabular}

Table 4.2.Paired Samples Correlations

\begin{tabular}{|ll|l|l|l|}
\hline & N & Correlation & Sig. \\
\hline Pair 1 Lexical \& Discourse & 40 & -.006 & .972 \\
\hline
\end{tabular}

Table 4.3.Paired Samples Test

\begin{tabular}{|c|c|c|c|c|c|c|c|c|}
\hline & \multicolumn{5}{|c|}{ Paired Differences } & \multirow[b]{3}{*}{$\mathrm{t}$} & \multirow[b]{3}{*}{ df } & \multirow{3}{*}{$\begin{array}{l}\text { Sig. } \\
\text { (2-tailed) }\end{array}$} \\
\hline & \multirow[b]{2}{*}{ Mean } & \multirow{2}{*}{$\begin{array}{l}\text { Std. } \\
\text { Deviation }\end{array}$} & \multirow{2}{*}{$\begin{array}{l}\text { Std. } \\
\text { Error } \\
\text { Mean }\end{array}$} & \multicolumn{2}{|c|}{$\begin{array}{l}\text { 95\% Confidence } \\
\text { Intervalof the } \\
\text { Difference }\end{array}$} & & & \\
\hline & & & & Lower & Upper & & & \\
\hline Pair 1 Lexical - Discourse & -62.06251 & 11.39525 & $\begin{array}{l}1.8017 \\
5\end{array}$ & -65.70688 & -58.41812 & -34.446 & 39 & .000 \\
\hline
\end{tabular}

The results of the Tables 4.1 and 4.3 revealed that there was a significant difference in the means of the scores for teachers in terms of using lexical $(M=27.43, S D=9.26)$ discourse- based $(M=89, S D=6.58) C S s$. The significance value 0 was less than $\mathrm{P}<0.05$ which revealed that the difference was meaningful.

\subsection{Analysis of Items related to Lexical- based CSs in the Questionnaire}

Table 4.4 Frequency Distribution of Topic Avoidance CS

\begin{tabular}{|c|c|c|c|c|c|}
\hline & & Frequency & Percent & Valid Percent & Cumulative Percent \\
\hline \multirow[t]{5}{*}{ Valid } & Never & 20 & 50.0 & 50.0 & 50.0 \\
\hline & Rarely & 8 & 20.0 & 20.0 & 70.0 \\
\hline & Once in a while & 6 & 15.0 & 15.0 & 85.0 \\
\hline & Sometimes & 6 & 15.0 & 15.0 & 100.0 \\
\hline & Total & 40 & 100.0 & 100.0 & \\
\hline
\end{tabular}

Table 4.4 shows the percentage of teachers who answered 'never' in the items related to Topic Avoidance CS was 50, and teachers who answered 'rarely' was 20, and teachers who answered 'once in a while' and 'some times' were 50 . 
Table 4.5 Frequency Distribution of Message Abandonment CS

q2

\begin{tabular}{|ll|c|c|c|c|}
\hline & Frequency & Percent & Valid Percent & Cumulative Percent \\
\hline Valid & Never & 16 & 40.0 & 40.0 & 40.0 \\
& Rarely & 12 & 30.0 & 30.0 & 70.0 \\
& Once in a while & 12 & 30.0 & 30.0 & 100.0 \\
Total & 40 & 100.0 & 100.0 & \\
\hline
\end{tabular}

Table 4.5 shows the percentage of teachers who answered 'never' in the items related to Message Abandonment CS was 40, and teachers who answered 'rarely' rarely was 30, and teachers who answered 'once in a while' was 30.

Table 4.6 Frequency Distribution of Message Replacement CS

q3
\begin{tabular}{|ll|c|c|c|c|}
\hline & Frequency & Percent & Valid Percent & Cumulative Percent \\
\hline Valid & Never & 18 & 45.0 & 45.0 & 45.0 \\
& Rarely & 10 & 25.0 & 25.0 & 70.0 \\
& Once in a while & 8 & 20.0 & 20.0 & 90.0 \\
Sometimes & 4 & 10.0 & 10.0 & 100.0 \\
Total & 40 & 100.0 & 100.0 & \\
\hline
\end{tabular}

Table 4.6 shows the percentage of teachers who answered 'never' in the items related to Message Replacement CS was 45, and teachers who answered 'rarely' was 25 , and teachers who answered 'once in a while' was 20 and for 'sometimes' the percent is 10.

Table 4.7. Frequency Distribution of Code Switching CS

q4

\begin{tabular}{|ll|c|c|c|c|}
\hline & Frequency & Percent & Valid Percent & Cumulative Percent \\
\hline Valid & Never & 14 & 35.0 & 35.0 & 35.0 \\
& Rarely & 18 & 45.0 & 45.0 & 80.0 \\
& Once in a while & 6 & 15.0 & 15.0 & 95.0 \\
Sometimes & 2 & 5.0 & 5.0 & 100.0 \\
Total & 40 & 100.0 & 100.0 & \\
\hline
\end{tabular}

Table 4.7 shows the percentage of teachers who answered 'never' in the items related to Code Switching CS was 35, and teachers who answered 'rarely' was 45, and teachers who answered' once in a while' was 15 and for' sometimes' the percent is 5 . 
Table 4.8. Frequency Distribution of Foreignizing CS

Q5

\begin{tabular}{|ll|c|c|c|c|}
\hline & & Frequency & Percent & Valid Percent & Cumulative Percent \\
\hline Valid & Never & 16 & 40.0 & 40.0 & 40.0 \\
& Rarely & 18 & 45.0 & 45.0 & 85.0 \\
& Once in a while & 6 & 15.0 & 15.0 & 100.0 \\
& Total & 40 & 100.0 & 100.0 & \\
\hline
\end{tabular}

Table 4.8 shows the percentage of teachers who answered 'never' in the items related to Foreignizing CS was 40, and teachers who answered 'rarely' was 45, and teachers who answered' once in a while' was 15.

Table 4.9 Frequency Distribution of Literal Translation CS

q6

\begin{tabular}{|ll|c|c|c|c|}
\hline & Frequency & Percent & Valid Percent & Cumulative Percent \\
\hline Valid & Never & 24 & 60.0 & 60.0 & 60.0 \\
& 8 & 20.0 & 20.0 & 80.0 \\
& Rarely & 6 & 15.0 & 15.0 & 95.0 \\
Once in a while & 2 & 5.0 & 5.0 & 100.0 \\
Sometimes & 40 & 100.0 & 100.0 & \\
Total & & &
\end{tabular}

Table 4.9 shows the percentage of teachers who answered 'never' in the items related to Literal Translation CS was 60, and teachers who answered ' rarely' was 20 , and teachers who answered 'once in a while' was 15 and the percent of'sometimes' was 5.

Table 4.10 Frequency Distribution of Substitution CS

q7
\begin{tabular}{|ll|c|c|c|c|}
\hline & Frequency & Percent & Valid Percent & Cumulative Percent \\
\hline Valid & Never & 16 & 40.0 & 40.0 & 40.0 \\
& Rarely & 20 & 50.0 & 50.0 & 90.0 \\
& Once in a while & 2 & 5.0 & 5.0 & 95.0 \\
& Sometimes & 2 & 5.0 & 5.0 & 100.0 \\
& Total & 40 & 100.0 & 100.0 & \\
\hline
\end{tabular}

Table 4.10 shows the percentage of teachers who answered 'never' in the items related to Substitution CS was 40 , and teachers who answered 'rarely' was 50 , and teachers who answered 'once in a while' was 5 and the percent of 'sometimes' was 5 . 
Table 4.11 Frequency Distribution of Generalization CS

q8
\begin{tabular}{|ll|c|c|c|c|}
\hline & Frequency & Percent & Valid Percent & Cumulative Percent \\
\hline Valid & Never & 14 & 35.0 & 35.0 & 35.0 \\
& Rarely & 14 & 35.0 & 35.0 & 70.0 \\
& Once in a while & 6 & 15.0 & 15.0 & 85.0 \\
& Sometimes & 6 & 15.0 & 15.0 & 100.0 \\
& Total & 40 & 100.0 & 100.0 & \\
\hline
\end{tabular}

Table 4.11 shows the percentage of teachers who answered 'never' in the items related to Generalization CS was 35, and teachers who answered 'rarely' was 35, and teachers who answered 'once in a while' was 15 and the percent of 'sometimes' was 15.

Table 4.12 Frequency Distribution of Circumlocution CS

q9
\begin{tabular}{|ll|c|c|c|c|}
\hline & Frequency & Percent & Valid Percent & Cumulative Percent \\
\hline Valid & Never & 2 & 5.0 & 5.0 & 5.0 \\
& Rarely & 10 & 25.0 & 25.0 & 30.0 \\
& Once in a while & 12 & 30.0 & 30.0 & 60.0 \\
& Sometimes & 14 & 35.0 & 35.0 & 95.0 \\
& Almost always & 2 & 5.0 & 5.0 & 100.0 \\
& Total & 40 & 100.0 & 100.0 & \\
\hline
\end{tabular}

Table 4.12 shows the percentage of teachers who answered 'never' in the items related to Circumlocution CS was 5, and teachers who answered 'rarely' was 25, and teachers who answered 'once in a while' was 30 and the percent of 'sometimes' and 'always' were 35 and 5 respectively.

Table 4.13 Frequency Distribution of Exemplification CS

\begin{tabular}{|c|c|c|c|c|c|}
\hline & & Frequency & Percent & Valid Percent & Cumulative Percent \\
\hline \multirow[t]{5}{*}{ Valid } & Never & 2 & 5.0 & 5.0 & 5.0 \\
\hline & Rarely & 4 & 10.0 & 10.0 & 15.0 \\
\hline & Once in a while & 16 & 40.0 & 40.0 & 55.0 \\
\hline & Sometimes & 18 & 45.0 & 45.0 & 100.0 \\
\hline & Total & 40 & 100.0 & 100.0 & \\
\hline
\end{tabular}

Table 4.13 shows the percentage of teachers who answered 'never' in the items related to Exemplification CS was 5, and teachers who answered 'rarely' was 10, and teachers who answered 'once in a while' was 40 and the percent of' sometimes' was 45 . 
Table 4.14 Frequency Distribution of Word Coinage CS

q11

\begin{tabular}{|ll|c|c|c|c|}
\hline & Frequency & Percent & Valid Percent & Cumulative Percent \\
\hline Valid & Never & 14 & 35.0 & 35.0 & 35.0 \\
& Rarely & 18 & 45.0 & 45.0 & 80.0 \\
Once in a while & 4 & 10.0 & 10.0 & 90.0 \\
Sometimes & 4 & 10.0 & 10.0 & 100.0 \\
Total & 40 & 100.0 & 100.0 & \\
\hline
\end{tabular}

Table 4.14 shows the percentage of teachers who answered 'never' in the items related to Word Coinage CS was 35, and teachers who answered 'rarely' was 45, and teachers who answered 'once in a while' was 10 and the percent of 'sometimes' was 10.

Table 4.15 Frequency Distribution of Restructuring CS

q12

\begin{tabular}{|ll|c|c|c|c|}
\hline & Frequency & Percent & Valid Percent & Cumulative Percent \\
\hline Valid & Never & 10 & 25.0 & 25.0 & 25.0 \\
& Rarely & 26 & 65.0 & 65.0 & 90.0 \\
Once in a while & 4 & 10.0 & 10.0 & 100.0 \\
Total & 40 & 100.0 & 100.0 & \\
\hline
\end{tabular}

Concerning the respondents' answers to restructuring CS 25\% of the respondents selected "never", while $65 \%$ of them had selected "rarely" and $10 \%$ of them selected "once in a while".

Table 4.16 Frequency Distribution of Mime CS

q13

\begin{tabular}{|ll|c|c|c|c|}
\hline & Frequency & Percent & Valid Percent & Cumulative Percent \\
\hline Valid & Never & 18 & 45.0 & 45.0 & 45.0 \\
& Rarely & 10 & 25.0 & 25.0 & 70.0 \\
& Once in a while & 12 & 30.0 & 30.0 & 100.0 \\
& Total & 40 & 100.0 & 100.0 & \\
\hline
\end{tabular}

Concerning the respondents' answers to mime CS $45 \%$ of the respondents selected "never", while $25 \%$ of them had selected "rarely" and $30 \%$ of them selected "once in a while". 
Table 4.17 Frequency Distribution of Gesture CS

q14

\begin{tabular}{|ll|c|c|c|c|}
\hline & Frequency & Percent & Valid Percent & Cumulative Percent \\
\hline Valid & Never & 12 & 30.0 & 30.0 & 30.0 \\
& Rarely & 14 & 35.0 & 35.0 & 65.0 \\
Once in a while & 10 & 25.0 & 25.0 & 90.0 \\
Sometimes & 4 & 10.0 & 10.0 & 100.0 \\
Total & 40 & 100.0 & 100.0 & \\
\hline
\end{tabular}

Concerning the respondents' answers to gesture CS $30 \%$ of the respondents selected "never", while $35 \%$ of them had selected "rarely" and $25 \%$ of them selected "once in a while" and $10 \%$ of teachers selected sometimes.

Table 4.18 Frequency Distribution of Sound Imitation CS

\begin{tabular}{|c|c|c|c|c|c|}
\hline & & Frequency & Percent & Valid Percent & Cumulative Percent \\
\hline \multirow[t]{4}{*}{ Valid } & Never & 10 & 25.0 & 25.0 & 25.0 \\
\hline & Rarely & 24 & 60.0 & 60.0 & 85.0 \\
\hline & Once in a while & 6 & 15.0 & 15.0 & 100.0 \\
\hline & Total & 40 & 100.0 & 100.0 & \\
\hline
\end{tabular}

Concerning the respondents' answers to sound imitation CS $25 \%$ of the respondents selected "never", while $60 \%$ of them had selected "rarely" and $15 \%$ of them selected "once in a while".

Table 4.19 Frequency Distribution of Direct Appeal CS

\begin{tabular}{|c|c|c|c|c|c|}
\hline & & Frequency & Percent & Valid Percent & Cumulative Percent \\
\hline \multirow[t]{4}{*}{ Valid } & Never & 22 & 55.0 & 55.0 & 55.0 \\
\hline & Rarely & 14 & 35.0 & 35.0 & 90.0 \\
\hline & Once in a while & 4 & 10.0 & 10.0 & 100.0 \\
\hline & Total & 40 & 100.0 & 100.0 & \\
\hline
\end{tabular}

Concerning the respondents' answers to direct appeal CS $55 \%$ of the respondents selected "never", while $35 \%$ of them had selected "rarely" and $10 \%$ of them selected "once in a while". 
Table 4.20 Frequency Distribution of Indirect Appeal CS

q17

\begin{tabular}{|ll|c|c|c|c|}
\hline & Frequency & Percent & Valid Percent & Cumulative Percent \\
\hline Valid & Never & 4 & 10.0 & 10.0 & 10.0 \\
& Rarely & 24 & 60.0 & 60.0 & 70.0 \\
& Once in a while & 8 & 20.0 & 20.0 & 90.0 \\
Sometimes & 4 & 10.0 & 10.0 & 100.0 \\
Total & 40 & 100.0 & 100.0 & \\
\hline
\end{tabular}

Concerning the respondents' answers to indirect appeal CS $10 \%$ of the respondents selected "never", while $60 \%$ of them had selected "rarely" and $20 \%$ of them selected "once in a while" and $10 \%$ of the respondents selected sometimes.

Table 4.21 Frequency Distribution of Approximation CS

\begin{tabular}{|} 
q18 \\
\hline & & Frequency & Percent & Valid Percent & Cumulative Percent \\
\hline Valid & Never & 14 & 35.0 & 35.0 & 35.0 \\
& Rarely & 14 & 35.0 & 35.0 & 70.0 \\
& Once in a while & 8 & 20.0 & 20.0 & 90.0 \\
& Sometimes & 4 & 10.0 & 10.0 & 100.0 \\
& Total & 40 & 100.0 & 100.0 & \\
\hline
\end{tabular}

Concerning the respondents' answers to approximation CS $35 \%$ of the respondents selected "never", while $35 \%$ of them had selected "rarely" and $20 \%$ of them selected "once in a while" and $10 \%$ of the respondents selected sometimes option in the questionnaire.

Table 4.22 Frequency Distribution of Use of all purpose Words CS

\begin{tabular}{|c|c|c|c|c|c|}
\hline & & Frequency & Percent & Valid Percent & Cumulative Percent \\
\hline \multirow[t]{5}{*}{ Valid } & Never & 16 & 40.0 & 40.0 & 40.0 \\
\hline & Rarely & 6 & 15.0 & 15.0 & 55.0 \\
\hline & Once in a while & 14 & 35.0 & 35.0 & 90.0 \\
\hline & Sometimes & 4 & 10.0 & 10.0 & 100.0 \\
\hline & Total & 40 & 100.0 & 100.0 & \\
\hline
\end{tabular}

Concerning the respondents' answers to all purpose words CS $40 \%$ of the respondents selected "never", while $15 \%$ of them had selected "rarely" and $35 \%$ of them selected "once in a while" and $10 \%$ of the respondents selected sometimes option in the questionnaire. 
Table 4.23 Frequency Distribution of Use of Fillers CS

q20

\begin{tabular}{|ll|c|c|c|c|}
\hline & Frequency & Percent & Valid Percent & Cumulative Percent \\
\hline Valid & Never & 4 & 10.0 & 10.0 & 10.0 \\
& Rarely & 10 & 25.0 & 25.0 & 35.0 \\
Once in a while & 14 & 35.0 & 35.0 & 70.0 \\
Sometimes & 10 & 25.0 & 25.0 & 95.0 \\
Almost always & 2 & 5.0 & 5.0 & 100.0 \\
Total & 40 & 100.0 & 100.0 & \\
\hline
\end{tabular}

Concerning the respondents' answers to use of fillers CS $10 \%$ of the respondents selected "never", while $25 \%$ of them had selected "rarely" and $35 \%$ of them selected "once in a while" and $25 \%$ of the respondents selected sometimes and only $5 \%$ of them selected always option in the questionnaire.

\subsection{Analysis of items related to Discourse based CSsin the Questionnaire}

Table 4.24 Frequency Distribution of Comprehension Check CS

q21

\begin{tabular}{|ll|c|c|c|c|}
\hline & Frequency & Percent & Valid Percent & Cumulative Percent \\
\hline Valid & Sometimes & 6 & 15.0 & 15.0 & 15.0 \\
& Almost always & 34 & 85.0 & 85.0 & 100.0 \\
& Total & 40 & 100.0 & 100.0 & \\
\hline
\end{tabular}

Concerning the respondents' answers to comprehension check CS $15 \%$ of the respondents selected "sometimes" and $85 \%$ of them had selected "almost always" options in the questionnaire.

Table 4.25 Frequency Distribution of Clarification Request CS

q22

\begin{tabular}{|ll|c|c|c|c|}
\hline & Frequency & Percent & Valid Percent & Cumulative Percent \\
\hline Valid & Once in a while & 2 & 5.0 & 5.0 & 5.0 \\
& Sometimes & 18 & 45.0 & 45.0 & 50.0 \\
Almost always & 20 & 50.0 & 50.0 & 100.0 \\
Total & 40 & 100.0 & 100.0 & \\
\hline
\end{tabular}

Concerning the respondents' answers to clarification request CS $5 \%$ of the respondents selected "once in a while" and $45 \%$ of them had selected "sometimes" and $50 \%$ of them selected "almost always" options in the questionnaire. 
Table 4.26 Frequency Distribution of Topic Fronting CS

\begin{tabular}{|c|c|c|c|c|c|}
\hline & & Frequency & Percent & Valid Percent & Cumulative Percent \\
\hline \multirow[t]{4}{*}{ Valid } & Rarely & 2 & 5.0 & 5.0 & 5.0 \\
\hline & Sometimes & 6 & 15.0 & 15.0 & 20.0 \\
\hline & Almost always & 32 & 80.0 & 80.0 & 100.0 \\
\hline & Total & 40 & 100.0 & 100.0 & \\
\hline
\end{tabular}

Concerning the respondents' answers to topic fronting CS only $2 \%$ of the respondents selected "Rarely" and $15 \%$ of them had selected "sometimes" and $80 \%$ of them selected "almost always" options in the questionnaire.

Table 4.27 Frequency Distribution of Tonicity CS

q24
\begin{tabular}{|ll|c|c|c|c|}
\hline & Frequency & Percent & Valid Percent & Cumulative Percent \\
\hline Valid & Once in a while & 4 & 10.0 & 10.0 & 10.0 \\
& Sometimes & 10 & 25.0 & 25.0 & 35.0 \\
& Almost always & 26 & 65.0 & 65.0 & 100.0 \\
& Total & 40 & 100.0 & 100.0 & \\
\hline
\end{tabular}

Concerning the respondents' answers to tonicity CS only $10 \%$ of the respondents selected "Once in while" and $25 \%$ of them had selected "sometimes" and $65 \%$ of them selected "almost always" options in the questionnaire.

Table 4.28 Frequency Distribution of Lexical Repetition CS

\begin{tabular}{|c|c|c|c|c|c|}
\hline & & Frequency & Percent & Valid Percent & Cumulative Percent \\
\hline \multirow[t]{4}{*}{ Valid } & Once in a while & 6 & 15.0 & 15.0 & 15.0 \\
\hline & Sometimes & 14 & 35.0 & 35.0 & 50.0 \\
\hline & Almost always & 20 & 50.0 & 50.0 & 100.0 \\
\hline & Total & 40 & 100.0 & 100.0 & \\
\hline
\end{tabular}

Concerning the respondents' answers to lexical repetition CS $15 \%$ of the respondents selected "Once in while" and $35 \%$ of them had selected "sometimes" and $50 \%$ of them selected "almost always" options in the questionnaire. 
Table 4.29 Frequency Table of obtained scores for the use of lexical based CSs

\begin{tabular}{|c|c|c|c|c|c|}
\hline & & Frequency & Percent & Valid Percent & Cumulative Percent \\
\hline \multirow[t]{14}{*}{ Valid } & 16.25 & 4 & 10.0 & 10.0 & 10.0 \\
\hline & 17.5 & 2 & 5.0 & 5.0 & 15.0 \\
\hline & 18.75 & 2 & 5.0 & 5.0 & 20.0 \\
\hline & 21.25 & 4 & 10.0 & 10.0 & 30.0 \\
\hline & 23.75 & 6 & 15.0 & 15.0 & 45.0 \\
\hline & 25 & 2 & 5.0 & 5.0 & 50.0 \\
\hline & 26.25 & 4 & 10.0 & 10.0 & 60.0 \\
\hline & 28.75 & 4 & 10.0 & 10.0 & 70.0 \\
\hline & 31.25 & 4 & 10.0 & 10.0 & 80.0 \\
\hline & 32.5 & 2 & 5.0 & 5.0 & 85.0 \\
\hline & 38.75 & 2 & 5.0 & 5.0 & 90.0 \\
\hline & 45 & 2 & 5.0 & 5.0 & 95.0 \\
\hline & 52.5 & 2 & 5.0 & 5.0 & 100.0 \\
\hline & Total & 40 & 100.0 & 100.0 & \\
\hline
\end{tabular}

Concerning the obtained results from paired t-test (Table 4.1) with the mean of (27.43) for lexical-based CSs used by EFL teachers, the frequencies of lexical-based CSs are shown in Table 4.29 show that $60 \%$ of respondents answered to lexical-based CSs less than the obtained mean (27.43) and $40 \%$ answered more than the obtained mean for lexical-based CSs.

Table 4.30 Frequency Table of obtained scores for the use of discourse based CSs

Discourse
\begin{tabular}{|lc|c|c|c|c|}
\hline \multicolumn{1}{|c|}{} & Frequency & Percent & Valid Percent & Cumulative Percent \\
\hline Valid & 75 & 2 & 5.0 & 5.0 & 5.0 \\
& 80 & 6 & 15.0 & 15.0 & 20.0 \\
& 85 & 2 & 5.0 & 5.0 & 25.0 \\
90 & 18 & 45.0 & 45.0 & 70.0 \\
& 95 & 8 & 20.0 & 20.0 & 90.0 \\
& 100 & 4 & 10.0 & 10.0 & 100.0 \\
& Total & 40 & 100.0 & 100.0 & \\
\hline
\end{tabular}

Concerning the obtained results from paired t-test (Table 4.1) with the mean of (89.50) for discoursebased CSs used by EFL teachers, the frequencies of discourse-based CSs are shown in Table 4.30 show that $25 \%$ of respondents answered to discourse-based CSs less than the obtained mean (89.50) and $75 \%$ answered more than the obtained mean for discourse-based CSs. 
Table 4.31 Descriptive Statistics for Lexical and Discourse base CSs

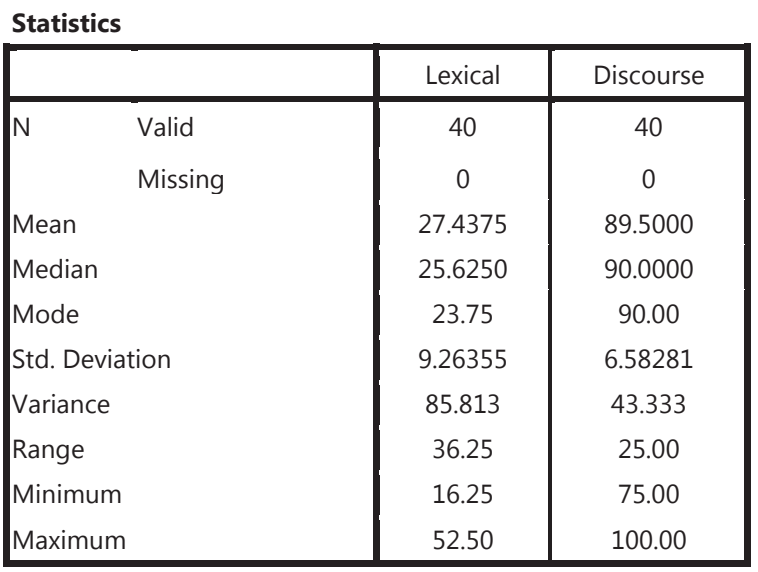

Table 4.31 shows that the mean of teachers score in items related to lexical-based was 27.43 and the standard deviation of the variable was 9.26 and minimum and maximum scores were 16.25 and 52.50, respectively. By comparing it with the teachers' answers to discourse-based CSs questions in the questionnaire, the mean of teachers score in items related to discourse base CSs was 89.50 and the standard deviation was 6.58 it was found that there was a significant difference between teachers in terms of using lexical and discoursebased CSs.

\section{Discussion and Conclusion}

This section represents the conclusion of the results and findings reported in the previous sections. It presents a discussion of the findings of the present research. It begins with discussion on the research hypothesis related to the research question. Next, pedagogical implications are discussed.

The main purpose of this study was to investigate the lexical and discourse-based CSs used by EFL teachers in Iranian context. Concerning the results of the study in chapter four, it was revealed that there was a significant difference in the means of scores for the teachers' use of lexical $(M=27.43, S D=9.26)$ and discourse $(\mathrm{M}=89.5, \mathrm{SD}=6.58)$ based CSs. The data confirming or rejecting this hypothesis were collected through a questionnaire, distributed to EFL teachers. The results drawn from these items were that EFL teachers used lexical and discourse-based CSs. The majority of EFL teachers used lexical-based CSs to compensate for lack of linguistic ability in their interlocutors. Analysis of items related to lexical based CSs revealed that, respondents mostly resorted to different kinds of achievement lexical-based CSs such as IL-based communication strategies (description, exemplification, substitution...), to compensate breakdowns in the communication. This finding is in line with (Bialystok 1983, Færch and Kasper 1983 and Paribakht 1985). According to obtained results by using the achievement or compensatory strategies, teachers tackled communication problems by an alternative plan for reaching their original goals. It seemed that EFL teachers used some other achievement lexical-based CSs, like use of fillers (to gain time to think), mime and gesture to help the effectiveness of teaching and fill the breakdowns in the communication. Compared to avoidance strategies, IL -based CSs are beneficial since they reflect the fact that learners make more positive attempts to tackle the difficulties they face in the process of communication.

Analysis of items related to discourse-based CSs revealed that the majority of EFL teachers used discourse based CSs as more proficient learners to enhance the effectiveness of communication in class. The analysis of the items revealed that most of the teachers used tonicity, topic fronting, lexical repetition to show salience of information to enhance the negotiation of meaning. This finding is in line with (Clennell 1995, Ting and Phan 2008, Ting and Lau 2008). According to Clennell (1995), CSs should not be viewed as being relevant only when the need for conversational repair arise, but that CSs can be used to facilitate the transfer of key 
information to alleviate breakdowns in communication. It seemed that EFL teachers used tonicity and topic fronting to emphasis the salience of the topic, they used lexical repetition to seek confirmation and topic maintenance to continue teaching discourse. So, it was concluded that discourse-based CSs were used for transfer of key information and effectiveness of teaching and communication process.

This study was set out to investigate lexical and discourse-based CSs used be EFL teachers in Iranian context. Analysis of the CSs using an integrated typology from Tarone (1977), Færch and Kasper (1983) and Clennell (1995) revealed some interesting results. The obtained results showed that irrespective of high language proficiency, EFL teachers used some IL-based CSs to compensate the breakdowns in the communication. Also, the results revealed that EFL teachers used discourse-based CSs more than lexical-based CSs to transfer the key information and emphasize the important topics in the communication process.

The present study is supposed to have some practical and pedagogical implications for the area of English language teaching and learning. This research is a preliminarily step in studying the lexical and discourse-based CSs used by teachers and can be considered as an opening to viewing the area of communicative competence and using CSs from a new dimension

By referring to the results of the study, teachers can become aware of their CS use in the classroom situations and the fact that they have either a little understanding about the area of CSs or a little awareness of the actual CSs they use in their classes. The present study was an attempt to inform teachers about using discourse-based CSs to focus on the salience of the information and negotiation of meaning. Raising this awareness accompanied by other studies reflecting on the effectiveness of the used CSs can lead to a better EFL learning situation for learners. Therefore, teachers can also learn how to become better and more efficient teachers.

\section{References}

Ansarin, A. (2003). Still a new inventory of communication strategies?The case of Iranian EFL learners.Tabriz University Faculty of Literature and Human Sciences Journal, 46, 17-43.

Applegate, J. L. (1980). Adaptive communication in educational contexts: A study of teachers' communication strategies. Communication Education, 29, 158-70.

Bialystok, E. (1983). Some factors in the selection and implementation of communication strategies. In C. Færch and G. Kasper (Eds.), Strategies in Interlanguage Communication (pp.100-118). Harlow: Longman.

Bialystok, E. (1990). Communication Strategies: A psychological analysis of second language use. Oxford: Basil Blackwell.

Canale, M. \& Swain, M. (1980). Theoretical bases of communicative approaches to second language teaching $\&$ testing. Applied Linguistics, 1, 1-47.

Canale, M. (1983).From communicative competence to communicative language pedagogy.In J.C. Richards, and R.W. Schmidt (Eds.), Language and Communication (pp.2-14). Harlow: Longman.

Chen, S.Q. (1991). A study of communication strategies in interlanguage production by Chinese EFL learners.Language Learning, 40, 155-187.

Huang, C.P. (2010). Exploring factors affecting the use of oral communication strategies .Department of Applied Foreign Languages.Lunghwa University of Science and Technology.

Clennell, C. (1994). Investigating the use of communication strategies by adult second language learners: A case for trusting your own judgment in classroom research.TESOL Journal, 3, 32-35.

Clennell, C. (1995). Communication strategies of adult ESL learners: A discourse perspective, Prospect, 10 (3), 4-20.

Clennell, C. (1996). Promoting the role of English prosody in a discourse-based approach to oral interaction.Prospect, 11(3), 17-28.

Clennell, C. (1997). Some arguments for raising the academic status of discourse intonation in ELT.ELT Journal (51), 2 : 106-117.

Clennell, C. (1999). "Promoting pragmatic awareness and spoken discourse skills with EAP classes." ELT Journal 53 (2), 83-91.

Cohen, A.D. (1987). Studying learner strategies: how we get the information. In A.L. Wenden\& J. Rubin (Eds.), Learner Strategies in Language Learning. Englewood Cliffs, N J: Prentice- Hall International.

Chiu, P. (2010), Exploring factors affecting the use of oral communication strategies. Department of Applied Foreign Languages Lunghawa University of Science and Technology.

Cook, V. (1991). Second language learning and teaching (pp. 67-71). Great Britain. 
Corder, S.P.(1967). The Significance of learners' errors.In C. Færch and G. Kasper (Eds.), Strategies in Interlanguage Communication. Harlow: Longman.

Corder, S. (1986). Error Analysis and Interlanguage (pp. 103-106). Oxford university press.

Dai, W. D., \&Shu, D.F.(1994).Research in communication strategies and its theoretical meaning in FL communication. FL Journal, 6, pp.27-31.

Dörnyei, Z. \&Thurrell, S. (1991). Strategic competence and how to teach it.ELT Journal, 45, 16-23.

Dörnyei, Z. \&Thurrell, S. (1994). Teaching conversational skills intensively: Course content and rationale .ELT Journal, 48, 40-49.

Dörnyei, Z. (1995). On the teachability of communication strategies.TESOL Quarterly, 29, 55-85.

Dörnyei, Z., and Scott, M.L. (1995a). Communication Strategies: what are they and what are they not? In Z. Dörnyei and M.L. Scott, Communication strategies in a second language: Definitions and taxonomies. Language Learning, 47, 173-210.

Dörnyei, Z., and Scott, M.L. (1995b). Communication Strategies: An empirical analysis with retrospection. In Z. Dörnyei, Z., and Scott, M.L.Scott, Communication Strategies in a second language: Definitions and taxonomies. Language Learning, 47, 173-210.

Dörnyei, Z. and Scott, M. (1997).Communication strategies in a second language.Definitions and Taxonomies.Language learning 47, 173-210.

Ellis, R. (1994). The study of second language acquisition (pp. 396-403, 471-499). Oxford: Oxford university press.

Ellis, R. (2003). Task-based language learning and teaching (pp.70-75). Oxford: Oxford university press.

Færch, C., \& Kasper, G. (1983).Strategies in interlanguage communication. London: Longman.

Færch, C., \& Kasper, G. (1983a). Plans and strategies in foreign language communication. In C. Færch, C., \& Kasper, G.(Eds.), Strategies in interlanguage communication (pp.20-60). Harlow, England: England: Longman.

Færch, C., \& Kasper, G. (1983b). Plans and Strategies in foreign language communication. In C. Færch, C., \& Kasper, G (Eds.), Strategies in Interlanguage Communication. Harlow: Longman.

Færch, C., \& Kasper, G. (1984).Two ways of defining communication strategies. Language Learning, 34, 45-63.

Faucette, P. (2001). A pedagogical perspective on communication strategies: Benefits of training and Analysis of English language teaching materials. Second Language studies, 19 (2).1-40.

Firth, A., and Wagner, J. (1997).On discourse, communication, and (some) fundamental concepts in SLA research.The Modern Language Journal, 81, 285-300.

Grice, H. (1957). Meaning. In E. Bialystok, Communication Strategies: A Psychological Analysis of Second Language Use. Oxford: Basil Blackwell.

Hsieh, H.H.(2005). A Study of Communication Strategies in Taiwan EFL College Learner's Spoken Language and Written Language.Master thesis, National Chengchi University, Taipei, Taiwan.

Huang, A.C. (2006). An investigation of communication strategy use in intercultural videoconferencing: A case study of TamkangUniversity English majors. Master's thesis, Tamkang University, Taipei, Taiwan.

Hyems, D. (1970). On communicative competence. In K.Johnson, and H. Johnson, Encyclopedic Dictionary of Applied Linguistics. Oxford: Blackwell Publishers Ltd.

Johnson, K., and, H. (1999).Encyclopedic Dictionary of Applied Linguistics. Oxford: Blackwell Publishers Ltd.

Karimialvar.N.andAliakbari, M \& (2008). Communication Strategies in the written Medium: The effect of language proficiency.

Kasper, G. \& Kellerman, E. (1983).Approaches to communication strategies. In communication strategies: Psychololingistic and Sociolinguistic perspectives. London. Longman.

King, J. (2001). Communication Strategies for Cross-cultural Interaction. The Crane Publishing Co. Ltd, Taiwan.

Lam, W.Y.K. (2006). Gauging the effects of ESL Oral Communication Strategy Teaching: A Multi-method Approach Journal of Foreign Language Teaching. Vol.3. No.2, 142-157.

Lee, J. F. (2006). The effects of teaching oral communication strategies on college students' learning performance and selfefficacy in an extension program.Master thesis, National Taiwan University of Science and Technology, Taipei, Taiwan.

Lynch, T. (1996). Communication in the language classroom.Oxford University Press.

Manchone, R. (1999). Fostering the autonomies use of communication strategies in the foreign language classroom.Links \& Letters 7, 13-27.

Mariani, L. (1994). Developing strategic competence: towards autonomy in oral interaction.Perspectives, a Journal of TESOL. Italy-Volume XX, number 1, 1994.

Mei, A. (2009). Use of communication strategies by Chinese EFL learners.Foreign Language Departement, Guizho University, China. 
Nakatani, Y. (2005). The effects of awareness-raising training on oral communication strategy use.The Modern Language Journal, 89 (1), 76-91.

Nakatani, Y. (2006). Developing an oral communication strategy inventory. The Modern Language Journal 90 (2), $151-168$.

Nakatani, Y. (2010). Identifying strategies that facilitate EFL learners' oral communication: A classroom study using multiple data collection procedures.The Modern Language Journal, 94(1), 116-136.

Nemser, W.J. (1971). Approximative systems of foreign language learners.In. C. Færch and G. Kasper (Eds.), Strategies in Interlanguage Communication. Harlow: Longman.

Paribakht, T. (1985).Strategic competence and language proficiency.Applied Linguistics, 6, 132-146.

Poulisse, N. (1987). Problems and solutions in the classification of compensatory strategies.Second Language Research, 3, 141-153.

Poulisse, N. (1993).A theoretical account of lexical communication strategies. In Z. Dörnyei and M.L. Scott, Communication strategies in a second language: Definitions and taxonomies. Language Learning, 47, 173-210.

Qiumei, B. (2004). Perception of Chinese EFL learners on communication difficulties and communicative strategies in use in the Australian context.

Rababah, G. (2005). Communication Problems Facing Arab Learners of English.Department of English language literature, college of Arts, King Saudi University.

Richard, J. (1992). Longman dictionary on language teaching and applied linguistics.Longman group.

Richard, J\& R, Schmidt (2002).Longman Dictionary of language teaching and applied linguistics.Pearson Education.

Schmitte, N. (2002). An introduction to applied linguistics (pp. 179-185).London Arnold.

Seliger, H., and Shohamy, E. (1989).Second Language Research Methods. Oxford: Oxford University Press.

Swain, M. (1985).Communicative competence some roles of comprehensible input and comprehensible output in its development. In S. Gass\& C. Madden (Eds.), Input in second language acquisition (pp. 235-256). New York: Newbury House.

Tarone, E., Cohen, A.D., and Dumas, G. (1976). A closer look at some interlanguage terminology: A framework for communication strategies. In C. Færch and G. Kasper (Eds.), Strategies in Interlanguage Communication. Harlow: Longman.

Tarone, E. (1977). Conscious communication strategies in interlanguage: A progress report. In Z. Dörnyei and M.L. Scott, Communication strategies in a second language: Definitions and taxonomies. Language Learning, 47, $173-210$.

Tarone, E. (1980). Communication strategies, foreigner talk and repair in interlanguage. Language Learning, 30, 417-431.

Tarone, E. (1981). Some thoughts on the notion of communication strategy TESOL Quarterly, 15, 285-295.

Tarone, E., Yule, G. (1987). Communication strategies in east-west interactions. In L. Smith, Discourse Across Cultures: Strategies in World Englishes. Hertfordshire: Prentice Hall International (UK) Ltd.

Ting, S.H.(2006). Lexical and discourse based communication strategies of Malaysian ESL learners. Malaysian Journal of ELT Research MELTA, 4, 18-31.

Ting, S.H and Grace Y.L (2008).Adjusting communication strategies to language proficiency.University Malaysia Sarawak, 23, 28-36.

Willems, G. (1987). Communication strategies and their significance in foreign language teaching.System 15(3) $351-364$.

Wolfson, N.( 1989). Perspectives: Sociolinguistics .TESOL. New York: Newbury House publishers.

Yang, D. \&Gai, F.P. (2010). Chinese learners' communication strategies research: a case study at ShandongJiaomtongUniversity. Cross-Cultural Communication, 6 (1), 2010, 56-81.

Yule, G. \&Tarone, E. (1990).Eliciting the performance of strategic competence.In Scarcella, Andersen, \&Krashen. Eds.(1990).Developing Communicative Competence in a Second Language. New York: Newbury House. 